\title{
The European Turtle Dove in the ecotone between woodland and farmland: multi-scale habitat associations and implications for the design of management interventions
}

\author{
Carles Carboneras $^{1,2}$ [D $\cdot$ Lara Moreno-Zarate $^{1}\left[\right.$ [D $\cdot$ Beatriz Arroyo $^{1}$ (i)
}

Received: 15 May 2021 / Revised: 12 November 2021 / Accepted: 25 November 2021 / Published online: 5 January 2022

(c) The Author(s) 2021

\begin{abstract}
The European Turtle Dove (turtle dove) is globally threatened after undergoing a sustained and generalised decline across its breeding range, with habitat loss suggested as the main driver. Here, we reviewed the scientific literature on habitat associations across its European breeding range, in relation to distribution, breeding numbers, nesting substrates, food and foraging habitats, to identify optimal habitat management measures. Large-scale distribution seemed related to the availability, but not dominance, of woodland landscapes; abundance was generally higher in woodland than on farmland. However, abundance in woodland increased with additional structural diversity and proximity to farmland, and abundance on farmland increased with greater availability of non-farmland features. Nesting occurred most frequently on trees (secondarily on bushes) but we found geographical differences in the type of nesting substrate, with thorny bushes being used more frequently in the north, and open canopy trees in the south. Turtle doves fed on a wide spectrum of seeds with a predominance of wild, particularly early-flowering, plants; but we could not identify a single plant species whose abundance determined turtle dove numbers. Across the distribution range, a shift from wild to cultivated seeds occurred as the season progressed. However, interventions should favour the availability and access to wild seeds. Efficient management interventions depend on the dominant habitat; overall, interventions should seek to augment landscape heterogeneity by increasing the mixing of farmland and woodland. Combined forestry and agricultural policies must provide the right conditions for ecotone species like the Turtle dove.
\end{abstract}

Keywords Streptopelia turtur $\cdot$ Migratory species $\cdot$ Conservation $\cdot$ Diet $\cdot$ Nesting $\cdot$ Species Action Plan

\section{Zusammenfassung}

Die Turteltaube im Übergangsbereich zwischen Wald und Ackerland: Zusammentreffen verschiedener Habitate und die Bedeutung für geeignete Managementmaßnahmen.

Die Turteltaube (Streptopelia turtur) ist weltweit bedroht, seitdem sie in ihrem gesamten Brutgebiet einen anhaltenden und allgemeinen Rückgang erlebt, vermutlich in erster Linie wegen des Verlusts von Lebensraum. Um optimale Maßnahmen für ein Habitat-Management herauszufinden, werteten wir die wissenschaftliche Literatur über die Lebensräume in ihren europäischen Brutgebieten in Hinblick auf Verbreitung, Anzahl Bruten, Nistmaterial, Nahrungs- und Ernährungshabitate aus. Die großräumige Verbreitung schien mit dem Vorhandensein von Waldlandschaften zusammenzuhängen, ohne dass dies aber eine vorherrschende Bedingung war. Die Turteltauben kamen im Allgemeinen in Wäldern häufiger vor als auf landwirtschaftlich genutzten Flächen. Aber die Häufigkeit nahm mit zusätzlicher Strukturvielfalt und der Nähe zu landwirtschaftlich genutzten Flächen zu und stieg auf diesen Flächen an, wenn sie mehr Charakteristika einer geringeren

Communicated by T. Gottschalk.

Carles Carboneras

carles.carboneras@rspb.org.uk

1 Instituto de Investigación en Recursos Cinegéticos (IREC)

(CSIC-UCLM-JCCM), Ciudad Real, Spain

2 Royal Society for the Protection of Birds, Sandy, UK 
landwirtschaftlichen Nutzung zeigten. Am häufigsten nisteten sie auf Bäumen (an zweiter Stelle auf Sträuchern), aber beim Nistmaterial fanden wir geographische Unterschiede, laut denen im Norden häufiger dornige Sträucher und im Süden eher offene Baumkronen genutzt wurden. Die Turteltauben ernährten sich von einer großen Auswahl an Samen, bei denen Wildpflanzen, insbesondere Frühblüher, überwogen; wir konnten aber nicht eine einzelne Pflanzenart feststellen, deren Vorkommen die Anzahl der Turteltauben bestimmte. Im gesamten Verbreitungsgebiet zeigte sich mit fortschreitender Jahreszeit eine Verschiebung von Wildsamen zu Kultursamen. Management-Maßnahmen sollten aber jedenfalls die Verfügbarkeit von und den Zugang zu Wildsamen fördern. Effiziente Maßnahmen hängen davon ab, welcher Habitattyp vorherrscht; generell sollten sie darauf abzielen, die Vielfalt der Landschaft durch einen stärkeren Mix von landwirtschaftlich genutzten Flächen und Wäldern zu erhöhen. Eine kombinierte Forst- und Agrarpolitik muss die richtigen Bedingungen für ökotone Arten wie die Turteltaube schaffen.

\section{Introduction}

The globally threatened European Turtle Dove (Streptopelia turtur; hereafter, turtle dove) is one of Europe's most rapidly declining species and a priority for conservation. In 2015, it was uplisted to the IUCN Vulnerable category, following a $>30 \%$ population loss in 3 generations (BirdLife International 2015). The first EU management plan on the species (Boutin and Lutz 2007) failed to achieve its conservation objectives. Following that, an International Single Species Action Plan (SAP) (Fisher et al. 2018) was adopted to tackle the main identified threats: habitat loss and deterioration on the breeding and wintering grounds, illegal killing and unsustainable hunting during migration. The top conservation objective of the turtle dove SAP was to maintain and increase good quality habitats on the breeding grounds, with available and accessible water and food. Recognising further that current knowledge may be biased towards a small part of its distribution, an additional objective of the turtle dove SAP was to improve knowledge of habitat selection and dietary needs on the breeding grounds across its wide range. An improved understanding of the relationships between habitat and occurrence, numbers and nesting preferences would allow designing better management.

Although frequently portrayed as a farmland species (Dunn et al. 2018; PECBMS 2020), a wealth of published work indicates that the turtle dove occupies a wider range of habitats during the breeding season, generally at low altitude (mostly below ca. $1000 \mathrm{~m}$ a.s.l.) and often combining open ground (arable or grassland) with hedges, trees or small woods (Kotov 1974; Peiró 1990; Dias and Fontoura 1996; Mason and Macdonald 2000; Browne et al. 2004; Browne and Aebischer 2005). Dominant extensive forest as well as heath are apparently avoided at least in some areas (Pikula and Beklová 1984; Bijlsma 1985; Gutiérrez 2001) but young plantations and managed woodlands, felled or coppiced, may hold high densities of breeding turtle doves (Kraus et al. 1972; Bijlsma 1985; Genard 1989; Gaitzenauer 1990; Browne et al. 2004; Fuller et al. 2004). The species has also been described as favouring disturbed conditions and typically not being found in climax plant communities. Thus, at a time when the species was abundant in the UK, the ecotone where deciduous woodland gives way to open grassland was described as its preferred habitat (Murton 1968).

The European Turtle Dove occupies a very large breeding range; for comparison, it is equivalent to 32-65 times the size of France, western Europe's largest country (Newton 1995; BirdLife International 2021). In this massive area, turtle doves must necessarily associate with multiple habitats and diverse landscapes. Our aim was to determine whether habitat associations in this species are general or contextspecific because this may have implications on whether recommendations for habitat management deduced from one particular area could be applicable elsewhere.

We reviewed the literature on turtle dove habitat associations across its European distribution at several spatial scales, from the breeding range (continental scale) to the individual nesting tree. We explored the relationship of habitat with large-scale distribution and of landscape characteristics with variations in density, and we examined studies of nesting and foraging habitats. As there was relatively little information on the latter, we also reviewed information on diet as a surrogate for habitats that would be suitable for foraging. We discuss our results in terms of habitat management for the species, and in terms of ecological requirements across some parts of the species' vast range.

\section{Methods}

We started by searching all the literature referenced in the two action plans (Boutin and Lutz 2007; Fisher et al. 2018) and the seven PhD theses (Rocha 1999; Browne 2002; Dias 2016; Gutiérrez-Galán 2017; Marx 2018; Bermúdez-Cavero 2020; Moreno-Zárate 2021) known to us that focused on the turtle dove's European breeding grounds. In addition, we reviewed all the papers cited in those works as well as all the recent literature on the species, through searches on the Web of Science (apps.webofknowledge.com), Google Scholar (scholar.google.com) and Connected Papers (www. connectedpapers.com) websites using the keywords "Streptopelia turtur" and "turtle dove", alone and in combination with "habitat", "farmland", "woodland" and "diet". We also added some additional references suggested by experts. 
Our analyses focused on the European breeding grounds; our objective was to provide a synthesis of evidence to help improve habitat management on the breeding grounds, to complement the propositions of the SAP, and we were interested in proposing habitat management measures that are applicable within this range as part of the SAP.

For plant species described as being consumed by turtle doves, we assessed whether they were annual, biennial or perennial according to information in World Flora Online (www.worldfloraonline.org), Encyclopedia of Life (www. eol.org) and Flora Ibérica (www.floraiberica.es). For studies made in the Iberian Peninsula, we also assessed flowering phenology from Flora-On www.flora-on.pt. We restricted that assessment to Iberia because the onset of spring progresses markedly from SW to NE throughout Europe (Menzel et al. 2005) and the Portuguese dataset was the only one available with complete phenological information including the very early part of the season.

\section{Results}

\section{Turtle dove large-scale distribution}

On a broad continental scale, the distribution of turtle doves appeared mostly associated to lower latitudes and warmer temperatures. The results of the distribution model for the second European Breeding Bird Atlas, EBBA2 (Keller et al. 2020), showed that latitude had the single heaviest weight $(32.5 \%)$ in predicting the probability of occurrence (PO) and that PO decreased sharply north of the $48^{\circ} \mathrm{N}$ line. Several additional variables related to temperature had a combined weight of 42\% (Supporting Online Information table S3). Of these, the most important climatic variables were the mean temperature during the entire breeding season, with a weight of $24 \%$, and the mean annual temperature, with 5.5\%. The European breeding distribution pattern thus fits with that of a thermophilic species linked to sustained warm temperatures over prolonged periods, confirming earlier studies at national level in the UK and Germany (Norris 1960; Kraus et al. 1972). Overall, $>85 \%$ of variation in PO in EBBA2 came from abiotic factors (geographic, climatic, human density, soil type), while factors associated to habitat contributed less than $15 \%$ to the model. On a continental scale, the only land cover variable with any significant effect in predicting variation in turtle dove $\mathrm{PO}$ was rainfed (= nonirrigated) cropland (weight: 6\%), with a positive relationship (Keller et al. 2020).

At a lower (national) scale, abiotic variables also seemed to be more important than land use to explain distribution in Germany (Marx and Quillfeldt 2018), mainly mild minimum temperatures in January (which might be linked to food availability during the early breeding season) and lower precipitation during the warmest quarter (which might relate to nestling survival), although models also suggested a quadratic relationship with forest cover, i.e., positive effects on PO when forest coverage was $>40 \%$ but negative when it was $>60 \%$.

In contrast, habitat characteristics seemed to be a much stronger determinant of distribution in Spain than topo-climatic factors. A study on turtle dove distribution at national scale (Moreno-Zárate et al. 2020) showed that turtle dove occurrence was positively but quadratically related to the availability of coniferous forests, sclerophyllous vegetation, olive groves and orchards, areas of complex cultivation patterns and mosaics of farmland and natural vegetation; the dominance of any of those vegetation types led to a decrease in PO.

\section{Relationships between habitat and breeding numbers at the landscape scale}

We found 34 studies, summarised in Tables S1a and S1b, that compared turtle dove relative abundance across different habitats in European landscapes (i.e., which made withinstudy comparisons of abundance or densities in different habitats): one third from the UK, another third from Spain, and the rest from several different countries. In 19 of those studies, within-study comparisons were made specifically between woodland and farmland habitats. In the majority of those $(n=16)$, relative abundance was higher in woodland than on farmland; the only exceptions came from one study in the UK and two studies in Spain (Table S1b). However, the two studies in Spain compared densities across very disjunct areas (Table S1a), so their results may be influenced by spatial variation in abundance for reasons unrelated to habitat (e.g., if the proportion of woodland is higher in study areas of higher altitude). Where assessed (one study each in Spain, Italy, Portugal and Bulgaria), riparian forests also showed high average densities compared to other habitats (Table S1a).

In woodland habitats, several features were associated with high turtle dove densities (Table S1b), including increased structure diversity (Hinsley et al. 1995); open canopy and thin tree cover (Camprodon and Brotons 2006; Sáenz de Buruaga et al. 2013); forest/woodland clearings with grassy undergrowth (Dias et al. 2013); forest/woodland stands of intermediate age/size (Bakaloudis et al. 2009); and proximity to farmland (Szép et al. 2012; Gutiérrez-Galán et al. 2019). Fontoura and Dias (1996) mentioned lower human disturbance as one of the possible advantages of woodland over farmland.

On farmland, higher abundance in the UK, France, Italy, Austria and northern Spain was associated to the availability of hedgerows, windbreaks and woodland edges (Gaitzenauer 1990; Aubineau and Boutin 1998; Browne 
et al. 2004; Sáenz de Buruaga et al. 2013; Chiatante et al. 2020) (Table S1b); in Mediterranean environments of the Iberian Peninsula, higher abundance was found in areas with high availability of tree crops (Dias et al. 2013; Moreno-Zárate et al. 2020). The presence of patches of natural vegetation (scrub, natural woodland, or fallow) appeared to have positive effects for turtle doves on farmland (Fernández and Camacho 1989; Gaitzenauer 1990; Dunn and Morris 2012; Dias 2016; Tree 2018; Dunn et al. 2021; Bermúdez-Cavero et al. 2021).

Two of the reviewed studies (Table S1a) found that turtle dove presence in Spain was positively associated with the number of water points (Sáenz de Buruaga et al. 2013; Bermúdez-Cavero et al. 2021). Further north, only one study found a clear relationship between abundance and the availability of standing water (Dunn and Morris 2012).

Some of the 34 studies provided a sufficiently detailed description of the study sites, or it was possible to infer their characteristics from those of the general area, to allow a deeper understanding of the relationship between breeding numbers and habitat structure; they are summarised in Table 1. Assessment of those studies showed that in landscapes dominated by semi-natural habitats (i.e., where the unmanaged or non-farmland components within the farmland landscape occupied the biggest portion), turtle doves appeared to be more abundant in broadleaved or Mediterranean mixed woodland with an open canopy and an herbaceous understorey. Most often, grassy understoreys in those areas were associated with grazing or browsing herbivores.

In semi-transformed landscapes, where farmland mixed with unmanaged woodland areas at the landscape level, the combination of trees and open spaces associated with higher breeding densities was more varied, although turtle doves also consistently associated with open canopy cover and an herbaceous understorey. Densities in broadleaved or mixed woodland were generally higher than in tree crops and conifers and, in turn, those held higher numbers than more open spaces such as arable land or grassland. Riparian forests also had high densities (although not necessarily the highest) in this type of landscape. The association with herbivory for maintaining the herbaceous understory was weaker (Table 1).

Where the farmland component of the landscape clearly dominated and wooded/unmanaged elements were small or isolated, turtle doves appeared to prefer wild or planted broadleaved and mixed stands, even if occurring in dense formations with closed canopy and a woody understorey (Table 1). More open habitats, such as residential areas, pasture and arable, had relatively lower nesting densities, and shrubs and hedgerows were commonly mentioned for breeding but not necessarily as the species' first choice.

Several of the above-mentioned studies also highlighted the positive effect of unpaved tracks on breeding densities
(Mason and Macdonald 2000; Vreugdenhil-Rowlands 2020; Bermúdez-Cavero et al. 2021). This may be related to the association of tracks with ruderal plants (see also below) and the fact that seeds may be more easily accessible in the bare areas of tracks, or else to the fact that tracks increase landscape heterogeneity.

Most of the studies reviewed (Tables S1a, S1b and 1) were correlational; however, a few studies were quasi-experimental, showing before-after relationships. In Catalonia (Spain), a forest management experiment linked to wildfire prevention showed that turtle doves responded positively to undergrowth clearing; their numbers increased following the removal of the understorey and the thinning of trees (Camprodon and Brotons 2006). In Kent (UK), after the coppicing of a plot of Sweet Chestnut Castanea silva woodland, numbers of turtle dove gradually increased and peaked when the woodland was 14 years, by which time the canopy had closed, the field layer had disappeared, and the ground was bare (Fuller and Moreton 1987). A rewilding experiment in the UK saw territories increase from 0 to 16 following the restoration of intensive farmland to its natural uncultivated state and the introduction of herbivores. The rootling action of pigs was shown to favour annual ruderal plants, although the direct effect on turtle doves was not demonstrated (Tree 2018; Klee 2019). Finally, also in the UK, the deployment of agri-environment schemes aiming to provide seed-rich habitats for turtle doves resulted in a slower temporal decline in the abundance of breeding males on intervention sites, reflecting enhanced habitat suitability for territory settlement (Dunn et al. 2021).

\section{Nesting substrates}

We found 19 studies containing information on the relative frequency of nest substrates used on the European breeding grounds, totalling more than 1800 nests (Table 2). Nests were reported from a wide variety of trees and shrubs, reflecting availability of tree species in its vast range but also revealing great flexibility in the use of nest substrate. We found indication of a latitudinal variation along the western flyway in the relative use of different tree species, possibly influenced by latitudinal differences in their availability, but trees with perennial leaves were used frequently at all latitudes (Fig. 1). Nests were most commonly situated on thorny bushes in more northerly areas, and these were replaced progressively further south by broadleaved trees and conifers, then by evergreen oaks (Quercus) and finally by olive trees in southern Iberia.

The regular presence of climbers ('lianas') on or over the nest was mentioned in some studies from France and UK (Aubineau and Boutin 1998; Browne and Aebischer 2004; Lormée 2015), and suggested as a protection to improve breeding success. In Mediterranean environments, 


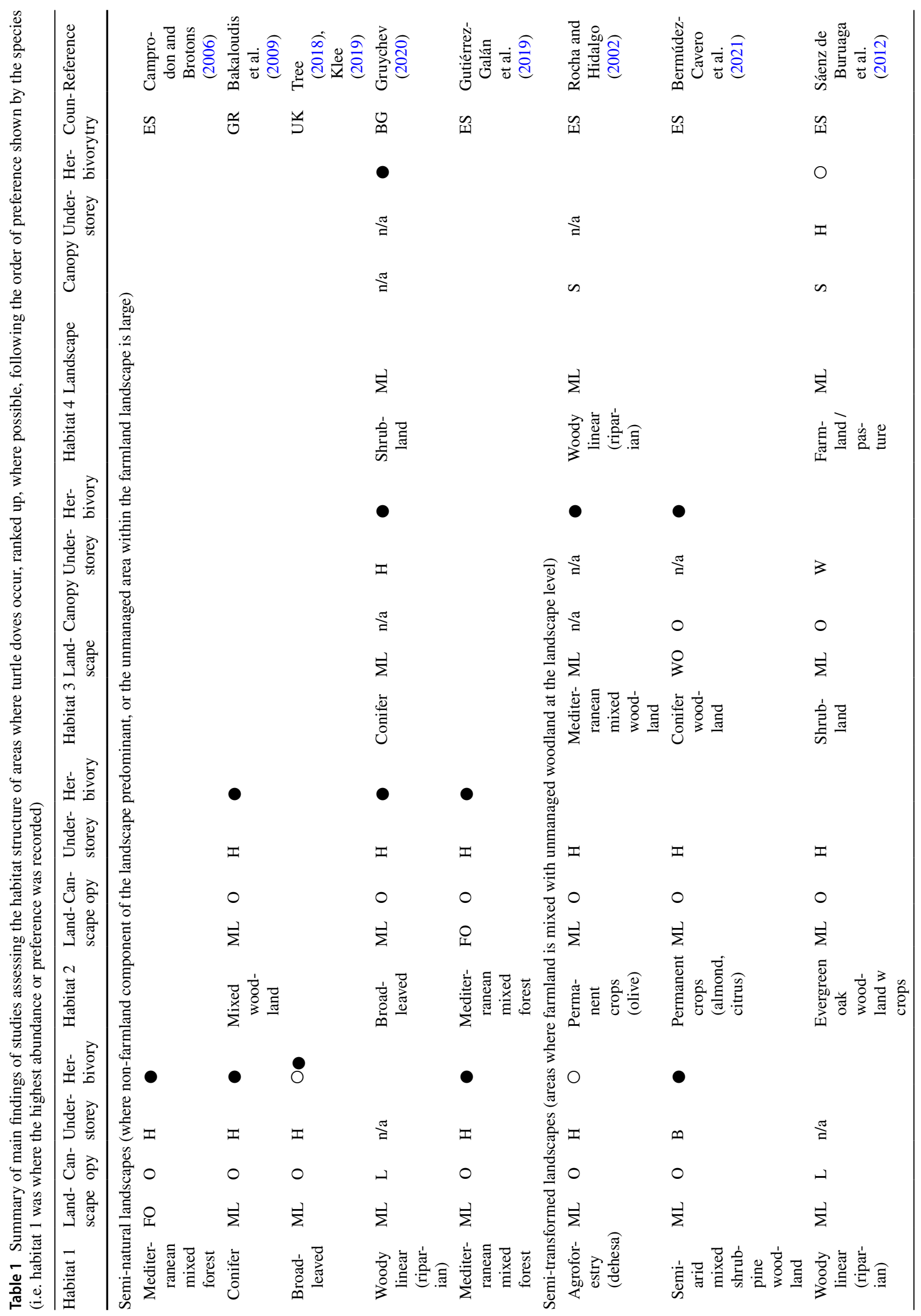




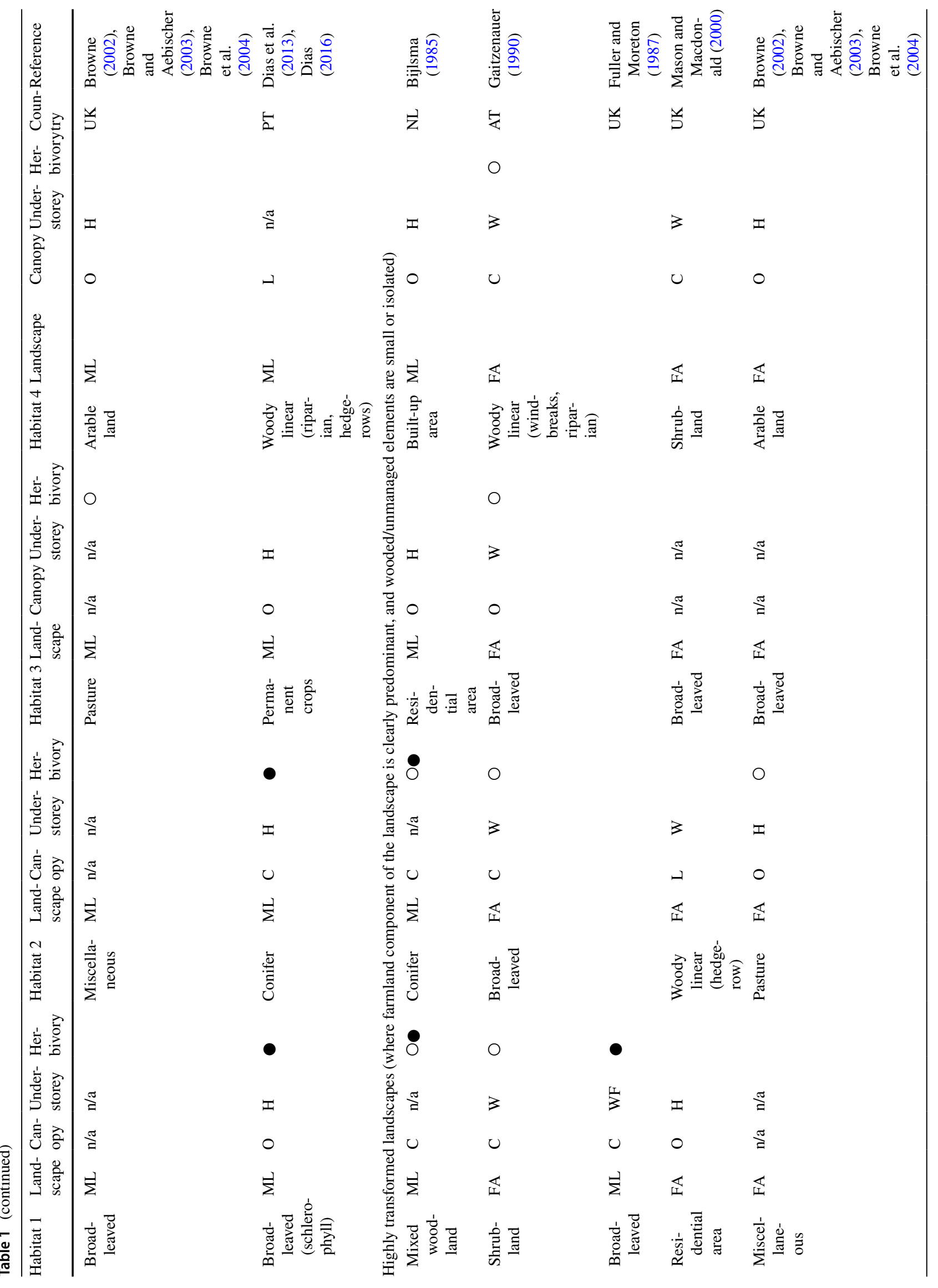


Journal of Ornithology (2022) 163:339-355

345

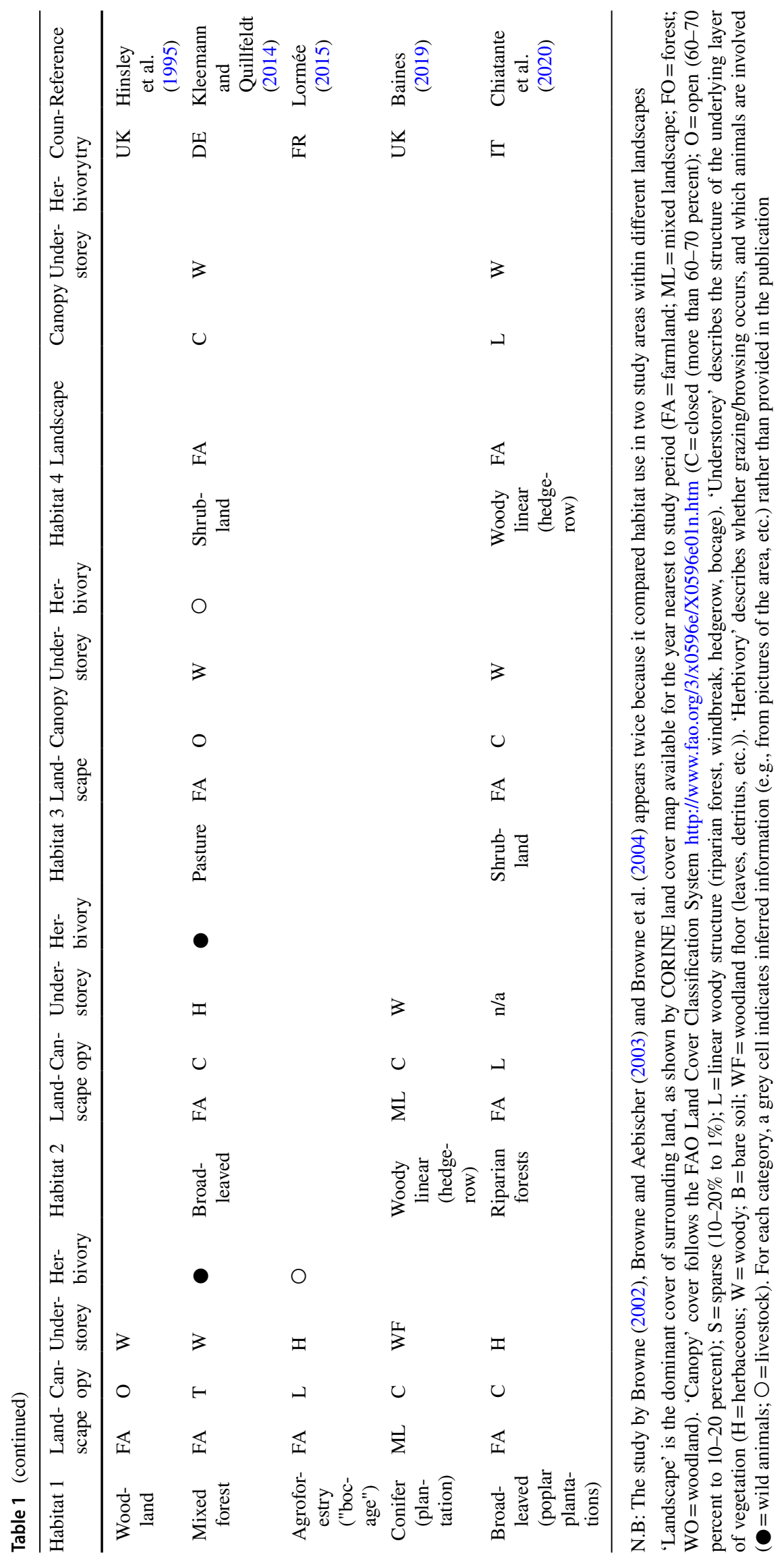

Springer 
Table 2 Summary of studies providing quantitative information on the use of nest substrates by turtle doves in Europe

\begin{tabular}{|c|c|c|c|c|c|}
\hline Country/region & Study year & Nests & Substrates used & Study type & Reference \\
\hline UK & $1962-1966$ & 511 & $\begin{array}{l}43 \% \text { Crataegus monogyna, } 17 \% \text { Sambucus } \\
\text { nigra, } 6 \% \text { Prunus spinosa, } 6 \% \text { wild rose } \\
\text { or bramble, } 5 \% \text { Salix, } 12 \% \text { other decidu- } \\
\text { ous trees, } 5 \% \text { conifers, } 3 \% \text { orchards or } \\
\text { ornamental trees, } 1 \% \text { Ilex aquifolium, } 1 \% \\
\text { Hedera helix and lonicera periclymenum, } \\
1 \% \text { Ulex europaeus }\end{array}$ & Peer-reviewed paper & Murton (1968) \\
\hline East Anglia (UK) & 1996 & 31 & $\begin{array}{l}\text { 65\% Crataegus monogyna, } 16 \% \text { Sambucus } \\
\text { nigra, } 6 \% \text { Prunus spinosa, } 3 \% \text { Acer pseu- } \\
\text { doplatanus, Picea albies, Malus silvestris, } \\
\text { Ulmus glabra }\end{array}$ & Report & Calladine et al. (1997) \\
\hline East Anglia (UK) & $1998-2000$ & 143 & $\begin{array}{l}64 \% \text { thorny bushes, } 13 \% \text { coniferous trees, } \\
10 \% \text { Elder, } 6 \% \text { broadleaved trees, } 6 \% \text { fruit } \\
\text { trees }\end{array}$ & Peer-reviewed paper & Browne and Aebischer (2004) \\
\hline Poitou (FR) & 1990`s & 59 & $\begin{array}{l}35 \% \text { Crataegus monogyna, } 30 \% \text { Coryllus } \\
\text { avellana, } 10 \% \text { Prunus spinosa, 5\% Acer } \\
\text { campestre, 5\% Euonymus europaeus, } 5 \% \\
\text { Pyrus communis, } 5 \% \text { Salix caprea, } 5 \% \\
\text { Sambucus nigra }\end{array}$ & Conference proceedings & Aubineau and Boutin (1998) \\
\hline France & 2000 ’s & & $\begin{array}{l}108 \text { species used, but Crataegus monogyna, } \\
\text { Prunus spinosa and Sambucus nigra } \\
\text { particularly favoured }\end{array}$ & Popular science & Lormée (2015) \\
\hline Czechia & $1933-1980$ & 259 & $\begin{array}{l}\text { 15\% Prunus spinosa, } 14 \% \text { Rosa canina, } \\
\text { 14\% Sambucus nigra, 13\% Picea abies, } \\
\text { 12\% Crataegus laevigata, } 6 \% \text { Prunus } \\
\text { spp., } 4 \% \text { Salix sp., 3\% Ulmus minor, } 9 \% \\
\text { other bushes, } 13 \% \text { other trees }\end{array}$ & Peer-reviewed paper & Pikula and Beklová (1984) \\
\hline Bulgaria & 2014-2016 & 37 & $\begin{array}{l}24 \% \text { Pinus nigra, } 16 \% \text { Quercus cerris, } 16 \% \\
\text { Quercus pubescens, } 8 \% \text { Ulmus minor, } 8 \% \\
\text { Acer negundo, } 8 \% \text { Paliurus spina-christi, } \\
\text { 8\% Salix sp.; 6\% Pyrus, 5\% Robinia } \\
\text { pseudocacacia }\end{array}$ & Peer-reviewed paper & Gruychev (2017) \\
\hline Pontevedra (ES) & 1989 & 5 & $\begin{array}{l}40 \% \text { Rubus ulmifoluis, } 20 \% \text { Betula celti- } \\
\text { berica, } 20 \% \text { Crataegus monogyna, } 20 \% \\
\text { Salix }\end{array}$ & Report & Fernández and Camacho (1989) \\
\hline Palencia (ES) & 1989 & 11 & $\begin{array}{l}54 \% \text { Rosa canina, } 18 \% \text { Rubus ulmifolius, } \\
\text { 9\% Crataegus monogyna, } 9 \% \text { Salix, } 9 \% \\
\text { Ulmus }\end{array}$ & Report & Fernández and Camacho (1989) \\
\hline Barcelona (ES) & 1989 & 3 & $\begin{array}{l}\text { 33.3\% Juniperus oxycedrus, } 33.3 \% \text { Quercus } \\
\text { faginea, } 33.3 \% \text { Rubus ulmifolius }\end{array}$ & Report & Fernández and Camacho (1989) \\
\hline Madrid (ES) & 1989 & 21 & $\begin{array}{l}\text { 33\% Rubus ulmifolius, } 19 \% \text { Crataegus } \\
\text { monogyna, } 19 \% \text { Salix, } 15 \% \text { Ulmus minor, } \\
\text { 9\% Quercus rotundifolia, 5\% Populus } \\
\text { nigra }\end{array}$ & Report & Fernández and Camacho (1989) \\
\hline Ciudad Real (ES) & 1989 & 51 & $\begin{array}{l}82 \% \text { Olea europaea, } 14 \% \text { Pinus halepensis, } \\
4 \% \text { Ceratonia siliqua }\end{array}$ & Report & Fernández and Camacho (1989) \\
\hline Caceres $(\mathrm{ES})$ & 1989 & 48 & $100 \%$ Quercus rotundifolia & Report & Fernández and Camacho (1989) \\
\hline Cordoba (ES) & 1989 & 68 & $\begin{array}{l}98 \% \text { Olea europaea, } 2 \% \text { Quercus rotundi- } \\
\quad \text { folia }\end{array}$ & Report & Fernández and Camacho (1989) \\
\hline Murcia (ES) & 1989 & 52 & $\begin{array}{l}87 \% \text { Olea europaea, } 11 \% \text { Pinus halepensis, } \\
2 \% \text { Ceratonia siliqua }\end{array}$ & Report & Fernández and Camacho (1989) \\
\hline Extremadura (ES) & 1996-1997 & 325 & $\begin{array}{l}\text { 76\% Quercus ilex rotundifolia; } 7 \% \text { Olea } \\
\text { europaea, } 6 \% \text { Pinus sp., } 3 \% \text { Quercus } \\
\text { suber, } 2 \% \text { Eucaliptus sp., <2\% Fraxinus } \\
\text { excelsior, Ficus carica, Quercus faginea, } \\
\text { Populus nigra, Alnus glutinosa, Salix, } \\
\text { Quercus pyrenaica, Populus alba, Arbu- } \\
\text { tus unedo }\end{array}$ & Book & Rocha and Hidalgo (2002) \\
\hline
\end{tabular}


Table 2 (continued)

\begin{tabular}{|c|c|c|c|c|c|}
\hline Country/region & Study year & Nests & Substrates used & Study type & Reference \\
\hline Spain & $2012-2013$ & 45 & $\begin{array}{l}25 \% \text { Pinus sp., } 18 \% \text { Olea europaea, } 18 \% \\
\text { Quercus ilex, } 14 \% \text { Quercus pyrenaica, } \\
12 \% \text { Fraxinus angustifolia, }<5 \% \text { Prunus } \\
\text { dulcis, Quercus coccifera, Juniperus sp., } \\
\text { Quercus faginea, Quercus coccifera }\end{array}$ & Report & Sáenz de Buruaga et al. (2013) \\
\hline $\begin{array}{l}\text { Castilla la Mancha } \\
\text { and Cataluña } \\
\text { (ES) }\end{array}$ & 2018-2019 & 64 & $\begin{array}{l}56 \% \text { Quercus sp., } 36 \% \text { Pinus sp., } 4 \% \text { Olea } \\
\text { europaea and Prunus dulcis, } 1 \% \text { Arbutus } \\
\text { unedo, } 1 \% \text { Juniperus oxycedrus }\end{array}$ & Conference poster & Arroyo et al. (2019) \\
\hline Algarve (PT) & 2003-2004 & 84 & $\begin{array}{l}41 \% \text { Quercus sp., } 19 \% \text { Olea europaea and } \\
\text { Prunus dulcis, } 12 \% \text { coniferous trees, } 4 \% \\
\text { broad-leaved trees, } 6 \% \text { thorny bushes, } \\
18 \% \text { other bushes }\end{array}$ & Conference poster & Dias and Rego (2017) \\
\hline
\end{tabular}

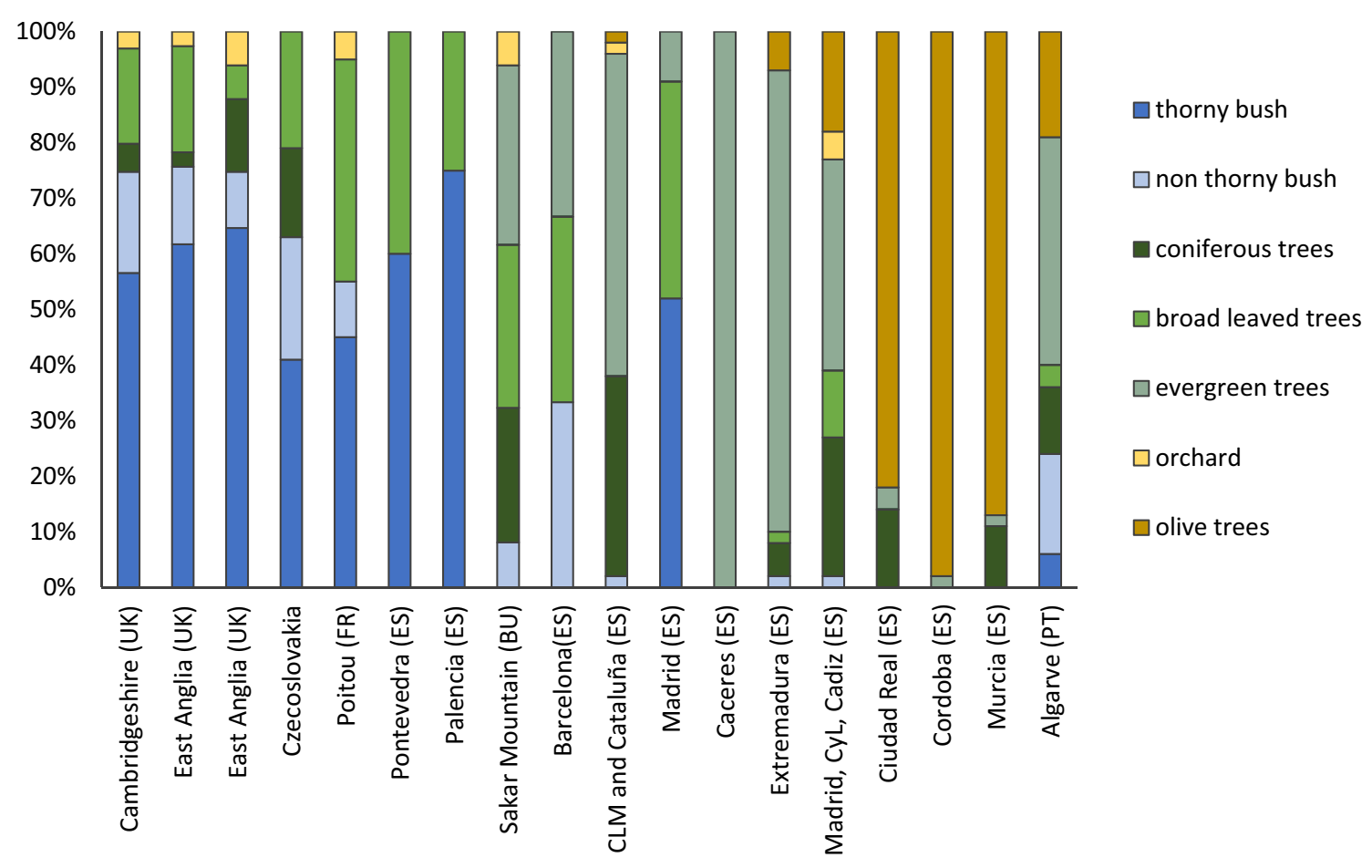

Fig. 1 Relative proportion of different nest substrates used by turtle doves for nesting in different study sites in Europe. Locations are ranked by latitude along the $x$ axis, from northernmost (left) to southernmost (right)

nests were generally more exposed, often on dispersed trees, and devoid of climbers (Sáenz de Buruaga et al. 2013; Dias 2016; Arroyo et al. 2019). Further east, in Austria and Czechia, nests were often situated in thorny bushes in both woodland and farmland, arguably to protect them from corvid predation (Pikula and Beklová 1984; Gaitzenauer 1990); in Bulgaria, nests were found predominantly on deciduous broadleaved and fruit trees (Nankinov 1994), but no mention was made of their association with thorns or lianas.

\section{Food, and feeding habitats}

The large number of seed types reported in studies from breeding grounds across Europe shows the wide variety of seeds consumed by the species (Table S2). Using the four categories in Dunn et al.'s (2018) analysis, most taxonomic units on the list of seed types consumed by turtle doves are known to occur naturally in the environment (77\%), whilst only $13 \%$ are cultivated (Table S2). Species of Amaranthaceae, Asteraceae, Boraginaceae, Brassicaceae, Caryophyllaceae, Fabaceae, Papaveraceae, Poaceae, Polygonaceae, or Ranunculaceae were the most frequently 
described in diet studies of turtle dove. This may indicate a preference for their seeds either because of their size, nutritional value or accessibility, although it would be necessary to have information on availability to be able to test for preferences. Studies assessing specifically seed availability are very scarce (Browne 2002; Gutiérrez-Galán 2017), and they suggest that seeds are taken in relation to availability, but further studies should be necessary to confirm this. In general, the species was found to feed mainly on annual ruderal plants growing wildly in disturbed environments (Fig. 2, Table S2). However, there was not one plant species to which turtle dove abundance or distribution would be particularly linked, and Irby's (1875) claims about the close association with Cerinthe major in Andalucía, Murton et al.'s $(1964,1965)$ about Fumaria officinalis in Britain and Russia or Gutiérrez-Galán et al.'s (2019) about Echium plantagineum also in Andalucía probably described only local phenomena, rather than general associations. We assessed the flowering phenology for the species reportedly taken as food in the Iberian Peninsula (Jiménez et al. 1992; Dias and Fontoura 1996; Gutiérrez-Galán and Alonso 2016). It showed that many species recorded in the turtle dove diet had long flowering periods (starting in March or before, and finishing in June-July or later), with flowering peaks in the period March to June, most prominently in April and May (Fig. 3). This is about one month earlier than the peak shown by the entire Portuguese flora (Flora-On 2014).

Few studies analysed the use of foraging habitat separately from that of breeding habitat. Turtle doves were mentioned to feed invariably on the ground (with the only exception of sunflower heads Helianthus (Garzón 1974)); several studies describe their principal habitat requirement

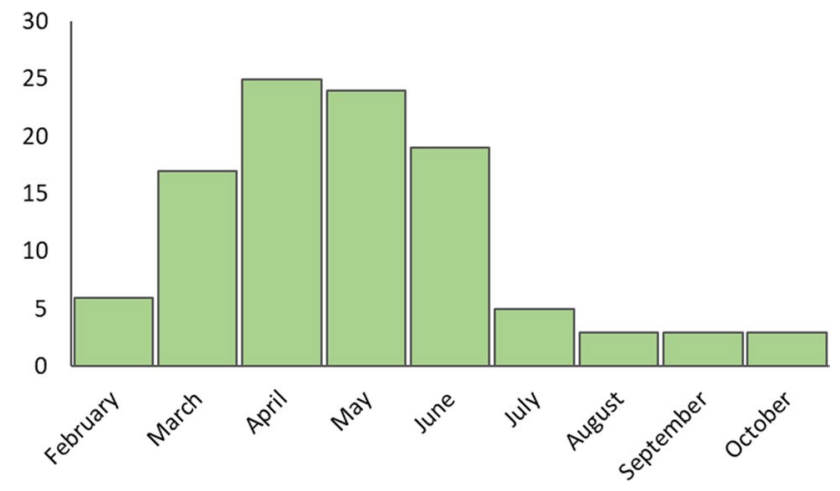

Fig. 3 Flowering phenology of plant species mentioned as turtle dove food in the Iberian Peninsula. Bars indicate the number of species that are described to have a peak flowering season in that month. Based on the information from the project Flora-On (2014), Flora de Portugal Interactiva. Sociedade Portuguesa de Botânica, available at www.flora-on.pt

for feeding as weed-rich areas with low open vegetation cover, hayfields, field strips, tracks and also as an herbaceous understorey within woodland or on land disturbed through tillage, burning or grazing (Mason and Macdonald 2000; Browne and Aebischer 2003; Bakaloudis et al. 2009; Dias et al. 2013; Gutiérrez-Galán et al. 2019; MorenoZárate et al. 2020; Vreugdenhil-Rowlands 2020). Birds tended to feed more often in natural environments during the first half of the breeding season and predominantly on cultivated seeds at the end of summer (Jiménez et al. 1992; Dias and Fontoura 1996; Browne and Aebischer 2003, 2005; Gutiérrez-Galán and Alonso 2016; Dunn et al. 2018). Turtle doves were also observed more commonly

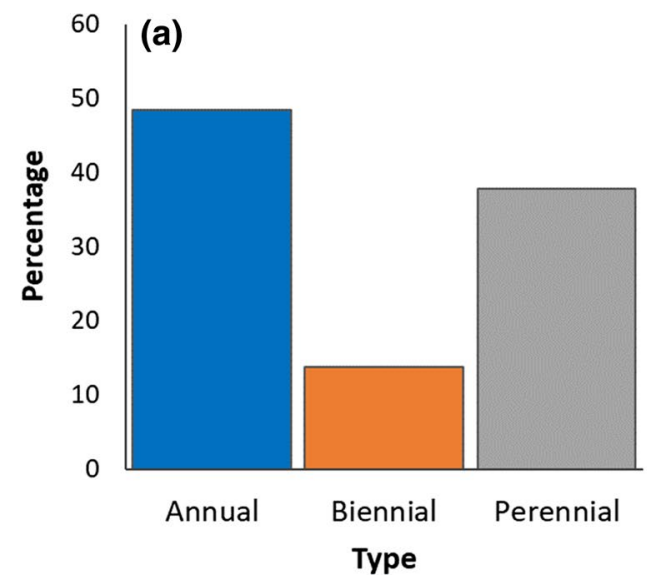

Fig. 2 Percentage of plant taxa mentioned as food taken by turtle doves (Table S2) in relation to whether they are annual, biannual or perennial (a) or in relation to their type (b). In the latter, categories follow the classification developed by Dunn et al. (2018): "brassica" (any form of Brassicaceae plant family, either provisioned, cultivated or wild); "cultivated" (crop plants and seed mixes sown to provide

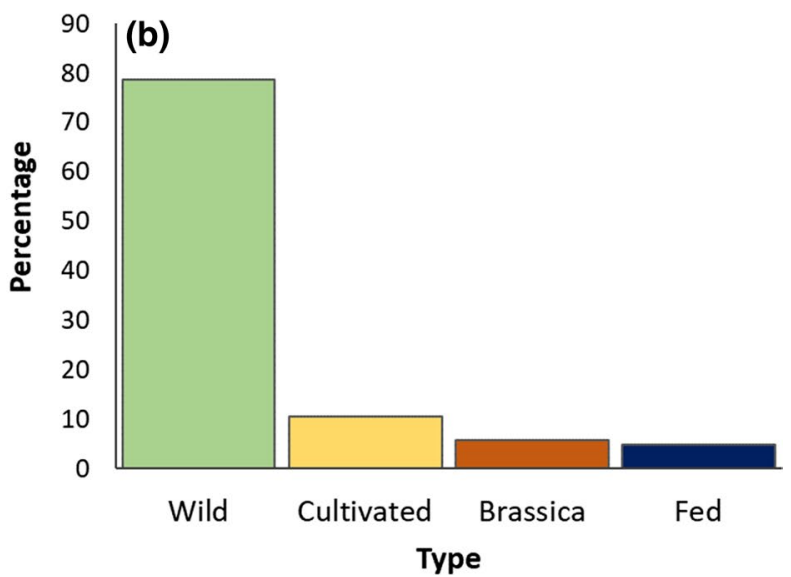

seed for game or wild birds); "fed" (seed from anthropogenic source, such as bird tables); "wild" (any wild plant species). Percentages were calculated as the proportion of taxa $(n=198)$ that fitted in each category out of the total list, bearing in mind that some taxa might fit in more than one category (e.g., a genus could have representatives in both the 'wild' and 'cultivated' groups) 
on farmland than on woodland later in the breeding season (Marja and Elts 2017). When available, birds made generalised use of man-made structures to feed on spilt grain in storage barns, silos, farmyards, manure heaps as well as on livestock feeding areas and game feeders (Mason and Macdonald 2000; Browne 2002; Browne and Aebischer 2003, 2005; Vreugdenhil-Rowlands 2020; Saâd et al. 2021a, b); in recent years, widespread use of bird feeders is known to occur in residential areas (Dunn et al. 2018).

The use of supplementary food (grain) provided especially at critical times (early on arrival, mostly at northern latitudes, and during the breeding season) has thus been proposed as an emergency conservation measure for the species (Fisher et al. 2018) and is regularly used as part of hunting management (https://www.fundacionartemi san.com/investigacion/pirte). A study in Spain (Rocha and Quillfeldt 2015) showed that sites where grain had been provided had a higher young/adult ratio in the birds observed by mid-August, suggesting that local breeding success could have been enhanced. But two experimental studies in the UK, where supplementary food was provided (Browne and Aebischer 2002) or seed-rich habitat was made available (Dunn et al. 2021), did not result in improved breeding success or nestling condition in the immediate area. Given the large feeding range of the species, Browne and Aebischer (2002) concluded that interventions should exceed 1000 ha to have a measurable effect. Moreover, the physical condition of nestlings was worse in those fed with crop seeds than in those fed with wild seeds (Dunn et al. 2015).

Many studies assumed that most of the foraging activity occurred within or near the breeding territories and, therefore, authors often recommended conservation interventions intended to provide seed-rich habitat in close proximity to suitable nesting habitat (Browne et al. 2004; Browne and Aebischer 2005; Dunn and Morris 2012; Fisher et al. 2018; Moreno-Zárate et al. 2020). While this could be true for many turtle dove territories, use of tracking technology has revealed that feeding sites could be spatially disjunct from breeding sites by up to $10 \mathrm{~km}$ (Calladine et al. 1997; Browne and Aebischer 2003; Gutiérrez-Galán and Alonso 2016; Arroyo et al. 2019; Vreugdenhil-Rowlands 2020). A recent study on farmland showed that home range size decreased with an increasing proportion of non-farmed habitat in the home range (Dunn et al. 2021), indicating that food was likely more easily obtained in the semi-natural parts of the farmland area; however, the presence of seed-rich habitats led to larger home ranges, suggesting that turtle doves expanded their home ranges to exploit those favoured areas. In general, turtle doves were shown to use grassland for foraging more often than expected from their availability, indicating that it was a preferred foraging habitat.

\section{Discussion}

\section{The European Turtle Dove as an ecotone species}

Our review has shown that the turtle dove should not be considered to associate predominantly to farmland, but rather to the ecotone between woodland and farmland, as stated by Murton (1968). Overall, large-scale (e.g., national) distribution seemed to be more linked to the availability (but not dominance) of woodland, and relative abundance at the landscape scale was also higher in woodland than on farmland. However, abundance increased in woodland when it was more structurally diverse and it was closer to farmland, and abundance on farmland increased with the presence of non-farmland features (e.g., woodland patches, shrubs or hedges), highlighting the preference for a mixture of habitats in this species.

Our review also showed a large variation in nesting substrates and food types consumed by turtle doves in line with the species' broad distribution over different habitats; this shows that the species can potentially adapt to a variety of habitats as far as they provide necessary nesting and feeding resources.

We discuss these topics below.

\section{Geographical variation in use of nesting substrates}

The available studies on nest site selection differed in search methodology, and this may influence the likelihood of finding nests in different substrates: nests situated on bushes or on low broadleaved and evergreen trees are easier for humans to find and they may thus occur disproportionately in studies based on cold searching; when this method was complemented with radio-tagging, the percentage of nests found on conifers and taller trees was much higher (cfr. Browne and Aebischer 2004; Arroyo et al. 2019).

However, and despite the potential effect of search methodologies on differences among studies, our review indicated marked geographical differences in the relative use of different substrates. Such differences may be explained by their relative availability. For example, extensive tree crops (almonds, olives) are commoner in southern Europe than in the north, and their proportion is even higher in North Africa; there, turtle dove nesting territories are mainly found in agricultural landscapes, like orange, apple or olive groves (Hanane and Baamal 2011; Hanane and Besnard 2014; Kafi et al. 2015; Hanane 2016; Mansouri et al. 2020), date palm plantations (Saâd et al. 2021a, b) or oases (Chedad et al. 2020; Hamza et al. 2021), in addition to woodland (Hanane and Yassin 2017; Rebbah et al. 2019). 
Moreover, differences in the risk of nest predation could explain the observed differences in nest substrates and characteristics of the nest: height, accessibility and exposure (Peiró 2001; Lormée 2015). The composition of predator communities varies spatially; while recorded predation was almost entirely by corvids in Britain (Murton 1968; Browne and Aebischer 2004; Browne et al. 2005), on continental Europe ground-based predators such as mammals and snakes also added to the guild, as did some birds of prey (Gaitzenauer 1990; Peiró 1990; Rouxel 2000; Rocha and Hidalgo 2002; Dias 2016; Sáenz de Buruaga et al. 2016; Arroyo et al. 2019). A strategy to hide nests in closed environments, often protected by thorns, might be a good response to a predominantly avian predation risk, since avian predators generally detect breeding birds from above and based on visual cues (Engel et al. 2020). Nests are often protected by thorns and lianas in northern and central Europe, and this might be a measure to reduce predation from birds (Gaitzenauer 1990; Aubineau and Boutin 1998; Browne and Aebischer 2005; Lormée 2015). Ground-based predators, on the other hand, may use other cues to locate their prey, and the turtle dove strategy to reduce the probability of being detected and attacked by ground predators may be to distance their nest from the tree trunk, as it has been observed in Mediterranean environments (Peiró 2001; Dias 2016; Arroyo et al. 2019). Whether the choice of nest substrate is related to a hypothetical protection from predators remains to be assessed, however, as well as whether there is a connection between the type of nesting substrate and nest success. So far, there is no evidence that variation in nest failure might be driving population trends (Browne 2002; Browne and Aebischer 2004). In contrast, productivity (the number of offspring produced per female and breeding season) in this species might be rather based on the ability to quickly produce a replacement clutch after a failed attempt. The number of breeding attempts per season has been suggested to be dependent on body condition and ultimately on food availability (Browne 2002). Improving access to abundant food may be more critical than changing conditions at the nesting sites for boosting turtle dove populations, something that had been highlighted by the SAP (Fisher et al. 2018).

\section{Presence of seeds of early-flowering wild plants in the diet}

Across the range, turtle doves have been shown to consume a wide variety of plant species. The observed geographical variation in their diet suggests that the actual choice is probably dependant on what is locally and temporally variable but, overall, our review highlights the large number of wild plant species whose seeds are eaten, and particularly of those that flower early and provide seeds at the appropriate time for breeding (Figs. 2 and 3, Table S2). Studies in UK show that the number of species providing ripe seed when birds arrive back at their breeding grounds may be very low (Browne 2002), indicating that food may be limiting in those circumstances.

During the first weeks after arrival to the breeding grounds, foraging will depend most heavily on wild seeds in all habitats, including woodland and farmland (Murton et al. 1964; Tyler 1994; Browne and Aebischer 2003; Gutiérrez-Galán et al. 2019); crucially, during this time period, breeding pairs will have raised their first brood (Arroyo et al. 2019). The first generation of chicks must thus be fed primarily on natural seeds, except in the few places where, e.g., birds have access to spilt grain from farmyards being moved from the storage barns (Browne and Aebischer 2003). It would therefore be important to maintain and enhance habitats that provide wild seeds. In the UK, higher number of weed species are found on rough ground rather than cropped or set-aside areas (Browne 2002). In Mediterranean woodland areas in Southern Spain, high densities of wild seed-producing plants are found in areas where the woodland area is intermixed with pasture areas (Gutiérrez-Galán and Alonso 2016).

In several parts of the distribution range, it has been shown that there is a shift from wild seeds to cultivated seeds as the season progresses (Murton et al. 1964; Rouxel 2000; Peiró 2001; Browne et al. 2004; Browne and Aebischer 2004; Dunn et al. 2015, 2018; Gutiérrez-Galán and Alonso 2016; Gutiérrez-Galán et al. 2019; Table S2). There is also a marked historical trend as the main diet has shifted from natural to cultivated seeds, which is well documented in places such as the UK, where changes in agricultural practices have reduced or removed many of the feeding opportunities available in the 1960s and 1970s (Browne and Aebischer 2001, 2004; Browne 2002). On the other hand, the introduction of new crops, such as sunflower Helianthus in Spain, has been very well accepted (Garzón 1974). Because crop seeds are more nutritious than wild seeds (Díaz 1990), they are probably preferred when both food types are available; this happens from mid-June in southern Europe and progressively northwards.

A study by Rocha and Quillfeldt (2015) showed that sites where grain had been provided had a higher young/adult ratio among birds present in mid-August, leading to the interpretation that local breeding success could have been enhanced. However, those results could also indicate that juveniles forage more often where food is both abundant and predictable, even if (relatively) far from the breeding site. In other words, such results demonstrate use of provisioned food in late summer by juveniles and adults, in line with the home range studies, but they do not necessarily prove better breeding success. Additionally, Dunn et al. (2018) finding 
that the nestling condition of chicks fed with crop seeds was worse than those fed with wild seeds further emphasizes the benefits of favouring access to the seeds of wild plants. In general, it is probably more beneficial to favour wild seeds, or a mix, rather than crop seeds alone when providing additional food.

\section{Is there a link between migration phenology and food availability in the early season?}

Given the large number of wild annual plant species highlighted in our review as ones whose seeds are consumed, these results suggest that migration phenology may be tuned to the availability of food on arrival from the wintering quarters. The turtle dove is one of the very few long-distance migrants that are also obligate granivores; of the 99 species of long-distance migratory birds in the Afro-Palaearctic system assessed by Moreau (1970), only two larks, three buntings, the Quail Coturnix coturnix and the turtle dove are wholly or largely dependent upon seeds; the other 92 species live on insects, some with a local and temporary supplement of berries. Compared to other Afro-Palaearctic bird species, the spring migration of the European Turtle Dove takes place relatively late in the season, with the bulk of birds arriving to the European shores between the end of April and early May. Irby (1875) and Brú (1913) already noticed this comparatively late phenology in the nineteenth century; the same pattern was observed through the twentieth century (Bernis and Castroviejo 1968; Nankinov 1994; Urcun et al. 1995; Rouxel 2000; Tryjanowski et al. 2002) and still continues at present (Fink et al. 2020). This late migration phenology may be an evolutionary adaptation to arrive to the breeding grounds when sufficient food is available, and not before.

\section{Recommendations for habitat management to favour turtle doves}

As a globally-threatened species (BirdLife International 2019), the turtle dove has justifiably received much attention from the conservation and scientific communities, who have proposed a number of practical habitat management measures aimed at reducing or reversing its ongoing population decline (Browne et al. 2004; Browne and Aebischer 2005; Bakaloudis et al. 2009; Dunn et al. 2015; Marx and Quillfeldt 2018). The internationally agreed Species Action Plan (Fisher et al. 2018) provides a list of recommendations for management with the objective to halt the species decline in the decade 2018-2028, and should be implemented as a matter of priority.

This review complements the Species Action Plan with a more specific analysis of habitat associations in the species.
In particular, evidence of the association of breeding numbers with type of habitat, or with certain habitat features, allows making suggestions for potential habitat interventions to boost turtle dove densities. Such improvements could play an essential role in consolidating population growth when they are linked with measures to increase survival (for example, through hunting regulations). Our review indicates that the most efficient habitat management interventions would depend on the dominant landscape (farmland or woodland) but that, overall, those interventions should seek to increase the mixing of farmland and woodland, i.e., to augment the ecotone between them. In other words, management actions to favour turtle doves should aim to retain or recover elements of heterogeneity in the landscape, combining and integrating patches of farmland, grassland and woodland in a mosaic pattern where possible. This means, in woodland, opening the canopy through thinning (if dense), creating clearings and preventing their subsequent encroachment; and on farmland, retaining or creating patches of shrub or areas with trees.

In all cases, it is important to ensure the provision of areas with high food availability, which is accessible for turtle doves, i.e., herbaceous grasslands with low vegetation height. Given the turtle dove's specialised diet on seeds, and the relevance of annuals in their diet (Fig. 3, Table S2), habitat management interventions aimed at increasing food availability at the beginning of the breeding period may allow earlier breeding and thus increased number of breeding attempts over the breeding period, something that forms the basis of conservation actions for the species in the UK (Browne and Aebischer 2004; Dunn and Morris 2012; Dunn et al. 2015, 2021). In southern European latitudes, food availability in the early season may be less limiting. It is generally assumed that farmland intensification in southern Europe is less acute, and ruderal plants are still widespread; at the same time, climate allows for early flowering (Fig. 3) at lower latitudes. However, it would be critical to make sure that this is still the case, and to favour the proliferation of early-flowering wild plants, e.g., by maintaining grassy margins between farmland plots, keeping weedy tracks on farmland and woodland, as well as maintaining woodland clearings through herbivory so they do not become encroached. Some of the studies in our review specifically suggest that maintaining extensive herbivory would be beneficial for this aim (particularly in woodland), and this could be achieved either with wild ungulates or extensive livestock farming (Gutiérrez-Galán and Alonso 2016; Gutiérrez-Galán et al. 2019).

The importance of water availability for the turtle dove has been frequently quoted in general studies (Fisher et al. 2018). However, water availability was cited less often than could have been expected in the reviewed studies, and its 
potential role to increase turtle dove breeding densities is not sufficiently clear. Indeed, a study in an agroforestry system in North Africa (where aridity is higher than in Europe), distance to a water point did not seem to have any predictive value for turtle dove nest habitat selection (Hanane 2018). This is an area that would clearly benefit from targeted research.

To summarise, priority recommended actions in treedominated areas include:

- Clear woodland undergrowth to provide an open woodland structure with only an herbaceous understorey; this can be part of fire prevention management

- Maintain or introduce grazing in woodland areas, by livestock or wild ungulates, at low densities and allowing for the proliferation of certain wildflowers (such as Echium plantagineum and Amaranthus deflexus) known to be part of the turtle dove's diet

On the other hand, priority recommended actions on farmland-dominated areas include:

- Maintain or promote elements of non-farmland habitats (natural grasslands, patches of woodland, shrub)

- Promote complex cultivation landscapes including grassy field margins and open areas (e.g., fallow land being ploughed in late winter) wherever possible

- After harvesting of cereal crops, retain stubble at least until October so that turtle doves have opportunities to feed on grain leftovers and ruderal plants growing in stubble (e.g., Chenopodium album); where grain storage occurs, allow birds to access spilt grain.

On both farmland and woodland landscapes, it would probably be useful to retain or open unpaved tracks with medium levels of disturbance (e.g., through public use) that allow for the proliferation of ruderal plants and other annuals in their margins, especially early flowering ones, and to allow those plants to complete their full reproductive cycle until they can offer seeds. Additionally, it would be necessary to ensure that enough suitable breeding habitat is available for turtle doves, adapted to the local choice of nest site characteristics.

\section{Conclusions}

The turtle dove is one of many migratory landbirds that are in decline in the Afro-Palaearctic system, many of which also have vast distribution ranges and therefore occupy an ample selection of habitats. Our review highlights that for this widespread species, and possibly for others as well, knowledge on habitat associations obtained at a small part of their vast range may not be representative of what happens elsewhere and should not be generalised. When designing habitat interventions to promote the conservation of any species, it may therefore be necessary to have evidence of habitat relationships from a large part of the range. In the case of the turtle dove, most of the evidence analysed in this review comes from studies in the United Kingdom, France, Spain and Portugal and it focuses on the population that migrates along the western flyway (Marx et al. 2016; Fisher et al. 2018; Lormée et al. 2019). In contrast, a comparatively reduced number of studies are available for the central-eastern flyway population, which highlights the need for more evidence from that part of the range.

Finally, our review highlights that for the many declining species that favour the ecotone between woodland and farmland in the Afro-Palaearctic system, forestry and agricultural policies need to be combined to provide the right conditions. The case of the turtle dove provides compelling evidence that too much of any one thing (farmland or woodland) is detrimental to the abundance of the species, as is too little. Management interventions are needed in both treedominated and farmland-dominated landscapes, to provide for the combination of open woodland interspersed with low grazing areas and complex cultivation systems with small parcels of mixed crop types, including woody permanent crops, where turtle dove populations have been shown to fare better. This may make it more complicated as more actors need to be involved. Also, it may make it more difficult to use certain resources (e.g. CAP funds) to provide exactly the right combination of measures needed in all places, as agri-environment schemes may not necessarily be applicable in woodland. This realisation highlights the need to look for joint initiatives between forestry, farming and conservation to guarantee the continuation of sustainable practices and the preservation of biodiversity-rich areas in the humandominated landscapes found across most of Europe.

Supplementary Information The online version contains supplementary material available at https://doi.org/10.1007/s10336-021-01946-1.

Acknowledgements We are indebted to Susana Dias and to Carolina Ruiz for helping locate some difficult-to-find references, and to Alexandre Czajkowski from OMPO, Migratory Birds of the Western Palearctic, for his assistance with publications in eastern Europe including Russia. We are also grateful to Sergi Herrando, Verena Keller and the European Bird Census Council for kindly allowing us to use the detailed outputs of the turtle dove distribution model prepared for the second European Breeding Bird Atlas EBBA2. We also thank two anonymous reviewers for their constructive comments that helped improve the manuscript, and for pointing us to some missed references.

Author contributions $\mathrm{CC}, \mathrm{LMZ}$ and $\mathrm{BA}$ conceived the study, researched the bibliography, completed the tables, discussed the results, and contributed equally to the manuscript. 
Funding This work was funded by the European Commission through contract ENV.D.3/SER /2019/0021 "Development of a population model and adaptive harvest mechanism for Turtle Dove (Streptopelia turtur)".

Availability of data and materials Not applicable.

Code availability Not applicable.

\section{Declarations}

Conflict of interest The authors declare that they have no conflict of interest.

Open Access This article is licensed under a Creative Commons Attribution 4.0 International License, which permits use, sharing, adaptation, distribution and reproduction in any medium or format, as long as you give appropriate credit to the original author(s) and the source, provide a link to the Creative Commons licence, and indicate if changes were made. The images or other third party material in this article are included in the article's Creative Commons licence, unless indicated otherwise in a credit line to the material. If material is not included in the article's Creative Commons licence and your intended use is not permitted by statutory regulation or exceeds the permitted use, you will need to obtain permission directly from the copyright holder. To view a copy of this licence, visit http://creativecommons.org/licenses/by/4.0/.

\section{References}

Arroyo B, Moreno-Zarate L, Fernández Tizón M, et al (2019) Parámetros poblacionales críticos para la tórtola europea: aplicaciones para su gestión. Instituto de Investigación en Recursos Cinegéticos (IREC) (CSIC-UCLM-JCCM), Ciudad Real

Aubineau J, Boutin J-M (1998) L'impact des modalités de gestion du maillage bocager sur les colombidés (columbidae) nicheurs dans l'ouest de la France. Gibier Faune Sauvage 15:55-63

Baines R (2019) Turtle Dove Surveys Report 2016-19 North Yorkshire Turtle Dove Project. North York Moors National Park, UK

Bakaloudis DE, Vlachos CG, Chatzinikos E et al (2009) Breeding habitat preferences of the turtledove (Streptopelia turtur) in the Dadia-Soufli National Park and its implications for management. Eur J Wildl Res 55:597

Bermúdez-Cavero A, Gil-Delgado JA, López-Iborra GM (2021) Modelling European turtle dove (Streptopelia turtur L. 1758) distribution in the south eastern Iberian Peninsula. Anim Biodivers Conserv. https://doi.org/10.32800/abc.2021.44.0279

Bermúdez-Cavero AO (2020) Ecología y selección de hábitat de la tórtola común (Streptopelia turtur Linnaeus , 1758) y tórtola turca (Streptopelia decaocto Frivaldszky, 1838) en el Este de España. $\mathrm{PhD}$ thesis. Valencia

Bernis F, Castroviejo J (1968) Aves de las islas Columbretes en primavera. Ardeola 12:143-163

Bijlsma RG (1985) De broedbiologie van de Tortelduif Streptopelia turtur. Het Vogeljaar 33:225-232

BirdLife International (2015) Streptopelia turtur. European Red List of Birds. Office for Official Publications of the European Communities, Luxembourg

BirdLife International (2019) Streptopelia turtur the IUCN red list of threatened species in: IUCN Red List Threat. Species. https:// doi.org/10.2305/IUCN.UK.2019-3.RLTS.T22690419A15437 3407.en
BirdLife International (2021) Species factsheet: Streptopelia turtur. http://www.birdlife.org. Accessed 3 Feb 2021

Boutin JM, Lutz M (2007) Management plan for turtle dove (Streptopelia turtur) 2007-2009. European Commission, Luxemberg

Browne SJ, Aebischer NJ (2002) The effect of supplementary feeding on territory size, territory density and breeding success of the Turtle Dove Streptopelia turtur: a field experiment. Asp Appl Biol 67:21-26

Browne SJ, Aebischer NJ (2003) Habitat use, foraging ecology and diet of Turtle Doves Streptopelia turtur in Britain. Ibis 145:572-582

Browne SJ, Aebischer NJ (2004) Temporal changes in the breeding ecology of European Turtle Doves Streptopelia turtur in Britain, and implications for conservation. Ibis 146:125-137. https://doi. org/10.1111/j.1474-919X.2004.00235.X

Browne SJ, Aebischer NJ (2005) Studies of West Palearctic birds: turtle dove. Br Birds 98:58-72

Browne SJ, Aebischer NJ, Yfantis G, Marchant JH (2004) Habitat availability and use by Turtle Doves Streptopelia turtur between 1965 and 1995: an analysis of Common Birds Census data. Bird Study 51:1-11

Browne SJ, Aebischer NJ, Crick HQP (2005) Breeding ecology of Turtle Doves Streptopelia turtur in Britain during the period 1941-2000: An analysis of BTO nest record cards. Bird Study 52:1-9. https://doi.org/10.1080/00063650509461368

Browne SJ, Aebischer NJ (2001) The role of agricultural intensification in the decline of the turtle dove Streptopelia turtur. English Nature

Browne SJ (2002) The breeding ecology of a declining farmland bird: the turtle dove Streptopelia turtur. PhD thesis, De Montfort University.

Brú F (1913) Notas de caza. José Guix, Valencia

Calladine JR, Buner F, Aebischer NJ (1997) The summer ecology and habitat use of the Turtle Dove: A pilot study. English Nature Research Reports No. 219, Peterborough

Camprodon J, Brotons L (2006) Effects of undergrowth clearing on the bird communities of the Northwestern Mediterranean Coppice Holm oak forests. For Ecol Manag 221:72-82

Carricondo A (2016) Analysis of environmental correlates of Turtle Dove Streptopelia turtur abundance in Spain using data from SACRE. SEO/BirdLife, Madrid

Chedad A, Bendjoudi D, Guezoul O (2020) New data on the wintering and sedentary life of the European Turtle Dove Streptopelia turtur in the Algerian northern Sahara. Curr Trends Nat Sci 9:65-73

Chiatante G, Porro ZENO, Meriggi A (2020) The importance of riparian forests and tree plantations for the occurrence of the European Turtle Dove Streptopelia turtur in an intensively cultivated agroecosystem. Bird Conserv Int. https://doi.org/10.1017/S0959 270920000532

Díaz M (1990) Interspecific patterns of seed selection among granivorous passerines: effects of seed size, seed nutritive value and bird morphology. Ibis 132:467-476. https://doi.org/10.1111/j. 1474-919X.1990.tb01064.x

Dias S, Rego F (2017) Caracterização dos locais de instalação dos ninhos de rola-brava: implicação para a gestão desta espécie vulnerável e cinegética. Viana do Castelo, Portugal, p 226

Dias S, Moreira F, Beja P et al (2013) Landscape effects on large scale abundance patterns of turtle doves Streptopelia turtur in Portugal. Eur J Wildl Res 59:531-541

Dias S, Fontoura AP (1996) The summer diet of the turtle-dove (Streptopelia turtur) in Southern Portugal. Rev Florest Port 9:227-241

Dias SM de A (2016) Critérios para a gestão sustentável das populações de rola-brava [Streptopelia turtur (L.)] em Portugal. Padrões de abundância, reprodução e pressão cinegética. PhD thesis, Universidad de Lisboa 
Dunn JC, Morris AJ (2012) Which features of UK farmland are important in retaining territories of the rapidly declining Turtle Dove Streptopelia turtur? Bird Study 59:394-402

Dunn JC, Morris AJ, Grice PV (2015) Testing bespoke management of foraging habitat for European Turtle Doves Streptopelia turtur. J Nat Cons 25:23-34

Dunn JC, Stockdale JE, Moorhouse-Gann RJ et al (2018) The decline of the Turtle Dove: dietary associations with body condition and competition with other columbids analysed using high-throughput sequencing. Mol Ecol 27:3386-3407

Dunn JC, Morris AJ, Grice PV, Peach WJ (2021) Effects of seed-rich habitat provision on territory density, home range and breeding performance of European Turtle Doves Streptopelia turtur. Bird Conserv Int. https://doi.org/10.1017/S0959270920000635

Engel N, Végvári Z, Rice R et al (2020) Incubating parents serve as visual cues to predators in Kentish plover (Charadrius alexandrinus). PLoS ONE 15:e0236489. https://doi.org/10.1371/journ al.pone.0236489

Fernández L, Camacho M (1989) Determinación de status de la Tórtola Común Streptopelia turtur. ICONA, Madrid

Fink D, Auer T, Johnston A, et al (2020) European Turtle Dove - eBird Status and Trends. In: Cornell Lab Ornithol. Ithaca N. Y. https:// ebird.org/ebird/science/status-and-trends/eutdov/abundancemap-weekly. Accessed 8 Mar 2021

Fisher I, Ashpole J, Scallan D, et al (2018) International Single Species Action Plan for the conservation of the European Turtle-dove Streptopelia turtur (2018 to 2028). Luxemb Eur Comm

Flora-On (2014) Flora de Portugal Interactiva. Sociedade Portuguesa de Botânica. www.flora-on.pt. Accessed 3 Sep 2021

Fontoura AP, Dias S (1996) Productivity of the turtle dove (Streptopelia turtur) in the northwest of Portugal. In: Proceedings of the XXII Congress of the International Union of Game Biologists, Sofia, September 1995. pp 1-7

Fuller RJ, Moreton BD (1987) Breeding bird populations of Kentish Sweet Chestnut (Castanea sativa) coppice in relation to age and structure of the coppice. J Appl Ecol 24:13. https://doi.org/10. 2307/2403784

Fuller RJ, Hinsley SA, Swetnam RD (2004) The relevance of nonfarmland habitats, uncropped areas and habitat diversity to the conservation of farmland birds. Ibis 146:22-31. https://doi.org/ 10.1111/j.1474-919X.2004.00357.x

Gaitzenauer K (1990) Die Bedeutung des Brutbiotopes der Turteltaube (Streptopelia turtur) im Seewinkel im Hinblick auf den Artenschutz. BFB-Ber 74:117-127

Garzón J (1974) Alteración en la conducta trófica de la Tórtola Común (Streptopelia turtur). Ardeola 20:362-363

Genard M (1989) Contribution à la connaissance de la tourterelle des bois (Streptopelia turtur) en Gironde (France): migration et nidification. Nos Oiseaux 40:11-24

Gruychev G (2020) Turtle Dove (Streptopelia turtur Linnaeus, 1758) Distribution Dependence of Habitat Variables in Central South Bulgaria. Ecologia Balkanica 12:137-146

Gutiérrez JE (2001) Les populations de tourterelles des bois en Andalousie. Faune Sauvage 253:36-43

Gutiérrez-Galán A, Alonso C (2016) European Turtle Dove Streptopelia turtur diet composition in Southern Spain: the role of wild seeds in Mediterranean forest areas. Bird Study 63:490-499

Gutiérrez-Galán A, López Sánchez A, Alonso González C (2019) Foraging habitat requirements of European Turtle Dove Streptopelia turtur in a Mediterranean forest landscape. Acta Ornithol 53:143-154

Gutiérrez-Galán A (2017) Aspectos aplicados de la ecología de la tórtola común (Streptopelia Turtur L.) en un ambiente forestal mediterráneo. $\mathrm{PhD}$ thesis, Universidad Politécnica de Madrid

Hamza F, Kahli A, Chokri M-A et al (2021) Urban and industrial landscapes interact with microhabitat to predict occurrence of European Turtle Dove (Streptopelia turtur) in Mediterranean oases: Implications for conservation. Landsc Urban Plan 215:104219. https://doi.org/10.1016/j.landurbplan.2021.104219

Hanane $S$ (2016) Effects of location, orchard type, laying period and nest position on the reproductive performance of Turtle Doves (Streptopelia turtur) on intensively cultivated farmland. Avian Res 7:4. https://doi.org/10.1186/s40657-016-0039-0

Hanane S (2018) Multi-scale turtle dove nest habitat selection in a Mediterranean agroforestry landscape: implications for the conservation of a vulnerable species. Eur J Wildl Res 64:45. https:// doi.org/10.1007/s10344-018-1205-y

Hanane S, Baamal L (2011) Are Moroccan fruit orchards suitable breeding habitats for Turtle Doves Streptopelia turtur? Bird Study 58:57-67. https://doi.org/10.1080/00063657.2010.518230

Hanane S, Besnard A (2014) Are nest-detection probability methods relevant for estimating turtle dove breeding populations? A case study in Moroccan agroecosystems. Eur J Wildl Res 60:673-680. https://doi.org/10.1007/s10344-014-0836-x

Hanane S, Yassin M (2017) Nest-niche differentiation in two sympatric columbid species from a Mediterranean Tetraclinis woodland: considerations for forest management. Acta Oecologica 78:4752. https://doi.org/10.1016/j.actao.2016.12.003

Hinsley SA, Bellamy PE, Newton I, Sparks TH (1995) Habitat and landscape factors influencing the presence of individual breeding bird species in woodland fragments. J Avian Biol 26:94. https:// doi.org/10.2307/3677057

Irby LHL (1875) The ornithology of the straits of Gibraltar. R. H. Porter, London

Jiménez R, Hodar JA, Camacho I (1992) La alimentación estival de la tórtola común (Streptopelia turtur) en el sur de España. Gibier Faune Sauvage 9:119-126

Kafi F, Hanane S, Bensouilah T et al (2015) Les facteurs déterminants le succès de reproduction de la Tourterelle des bois (Streptopelia turtur) dans un milieu agricole Nord-Africain. Rev Ecol 70:271-279

Keller V, Herrando S, Voříšek P et al (2020) European breeding bird atlas 2: distribution, abundance and change. European Bird Census Council \& Lynx Edicions, Barcelona

Kiss JB, Rekasi J, Sterbetz I (1978) Dati sull'alimentazione di alcune specie di ucelli nel nord della Dobrugia (Romania). Avocetta 2:3-18

Klee De I (2019) The vegetation of the pig rootled areas at Knepp Wildland and their use by Farmland Birds. Imperial College London, London

Kleemann L, Quillfeldt P (2014) Habitat use of Turtle Doves (Streptopelia turtur) in an agriculturally used area in Hessen. Vogelwarte 52:1-11

Kotov AA (1974) The ecology of the Turtle Dove in the southern Urals. Bull Mosc Soc Nat Biol Ser 79:36-43

Kraus M, Krauss W, Mattern U (1972) Zur verbreitung der Turteltaube (Streptopelia turtur) in Nordbayern. Anz Ornithol Ges Bayern 11:263-268

Lormée H (2015) Importance de l'habitat bocager pour une espèce à enjeu de conservation: la tourterelle des bois. Faune Sauvage 308:22-24

Lormée H, Barbraud C, Peach W et al (2019) Assessing the sustainability of harvest of the European Turtle-dove along the European western flyway. Bird Conserv Int. https://doi.org/10.1017/S0959 270919000479

Mansouri I, Ousaaid D, Squalli W et al (2020) The turtle dove (Streptopelia turtur) in Midelt plain, Morocco: nesting preferences and breeding success versus the impact of predation and agricultural practices. J Anim Behav Biometeorol 8:206-214

Marja R, Elts J (2017) Turteltuvide (Streptopelia turtur) elupaigakasutuse ja käitumismustri kirjeldus 2017. aastal kogutud andmete põhjal. Hirundo 30:46-56 
Marx M, Quillfeldt P (2018) Species distribution models of European Turtle Doves in Germany are more reliable with presence only rather than presence absence data. Sci Rep 8:1-13. https://doi. org/10.1038/s41598-018-35318-2

Marx M, Korner-Nievergelt F, Quillfeldt P (2016) Analysis of ring recoveries of European Turtle doves Streptopelia turtur-Flyways, migration timing and origin areas of hunted birds. Acta Ornithol 51:55-70

Marx M (2018) Population connectivity of European Turtle Doves (Streptopelia turtur) - Threats affecting European populations and modelling of species-habitat relationships at German breeding grounds. Justus-Liebig-Universität Gießen

Mason CF, Macdonald SM (2000) Influence of landscape and landuse on the distribution of breeding birds in farmland in eastern England. J Zool 251:339-348

Menzel A, Sparks TH, Estrella N, Eckhardt S (2005) 'SSW to NNE'North Atlantic Oscillation affects the progress of seasons across Europe. Glob Change Biol 11:909-918. https://doi.org/10.1111/j. 1365-2486.2005.00954.x

Moreau RE (1970) Changes in Africa as a wintering area for palaearctic birds. Bird Study 17:95-103. https://doi.org/10.1080/00063 657009476262

Moreno-Zárate L, Estrada A, Peach W, Arroyo B (2020) Spatial heterogeneity in population change of the globally threatened European turtle dove in Spain: the role of environmental favourability and land use. Divers Distrib 26:818

Moreno-Zárate L (2021) The status and hunting of European Turtledove (Streptopelia turtur) in Spain. PhD thesis, Universidad de Castilla-La Mancha

Murton RK (1968) Breeding, migration and survival of turtle doves. Br Birds 61:193-212

Murton RK, Westwood NJ, Isaacson AJ (1964) The feeding habits of the woodpigeon columba palumbus, stock dove C. Oenas and turtle dove streptopelia turtur. Ibis 106:174-188

Murton RK, Westwood NJ, Isaacson AJ (1965) Russian observations by G. N. Likhachev on the diet of the stock dove columba oenas and turtle dove streptopelia turtur. Ibis 107:254-256. https://doi. org/10.1111/j.1474-919X.1965.tb07303.x

Nankinov D (1994) The breeding biology of the turtle dove (Streptopelia turtur) in Bulgary. Gibier Faune Sauvage 11:155-165

Newton I (1995) Relationship between breeding and wintering ranges in Palaearctic-African migrants. Ibis 137:241-249. https://doi. org/10.1111/j.1474-919X.1995.tb03246.X

Norris CA (1960) The breeding distribution of thirty bird species in 1952. Bird Study 7:129-184

PECBMS (2020) Pan-European Common Bird Monitoring Scheme. https://pecbms.info

Peiró V (1990) Aspectos de la reproducción de la tórtola común (Streptopelia turtur, L.) en Madrid. Mediterránea Ser Estud Biológicos 12:89-95

Peiró V (2001) Écologie de la reproduction de la tourterelle des bois en Espagne. Faune Sauvage 253:63-65

Pikula J, Beklová M (1984) Bionomy of Streptopelia decaocto and S. turtur in Czechoslovakia. Acta Sci Nat Acad Sci Bohemoslov Brno 18:1-45
Rebbah AC, Menaa M, Telailia S et al (2019) Effect of habitat types on breeding bird assemblages in the Sidi Reghis Forests (Oum El Bouaghi, North-Eastern Algeria). Pak J Zool. https://doi.org/ 10.17582/journal.pjz/2019.51.2.433.447

Rocha G, Hidalgo S (2002) La tórtola común Streptopelia turtur. Análisis de los factores que afectan a su status. Universidad de Extremadura, Servicio de Publicaciones, Cáceres

Rocha G, Quillfeldt P (2015) Effect of supplementary food on age ratios of European turtle doves (Streptopelia turtur L.). Anim Biodivers Conserv 38:11-21

Rocha G (1999) Análisis de los Factores que Afectan al Estatus de la Tórtola Común (Streptopelia turtur) en Extremadura. $\mathrm{PhD}$ thesis, University of Extremadura

Rouxel R (2000) Turtle Dove (Streptopelia turtur): a review of bibliographical data from the Eastern Europe. OMPO Newsl 22:5-18

Saâd N, Hanane S, El Hak Khemis MD et al (2021a) Landscape composition governs the abundance patterns of native and invasive Columbidae species along an urban-rural gradient and contribute to their partitioning. Biol Invasions 23:2077-2091. https://doi. org/10.1007/s10530-021-02489-5

Saâd N, Hanane S, Farhi K et al (2021b) Tree characteristics, microhabitat and edge effect in plantations govern European Turtledove Streptopelia turtur nest habitat selection at the edge of Sahara: implications for conservation of a vulnerable species. Bird Conserv Int. https://doi.org/10.1017/S0959270921000290

Sáenz de Buruaga M, Onrubia A, Fernández-García JM et al (2013) Breeding habitat use and conservation status of the turtle dove Streptopelia turtur in Northern Spain. Ardeola 59:291-300

Sáenz de Buruaga M, Canales F, Robles JL (2016) Estudio sobre la reproducción de la tórtola en España I Trofeo caza. https://www. trofeocaza.com/caza-menor/reportajes-caza-menor/caza-menornacional/estudio-sobre-la-reproduccion-de-la-tortola-en-espana/. Accessed 8 Mar 2021

Szép T, Nagy K, Nagy Z, Halmo G (2012) Population trends of common breeding and wintering birds in Hungary, decline of long distance migrant and farmland birds during 1999-2012. Ornis Hung 20:13-63

Tree I (2018) Creating a mess-The Knepp Rewilding Project. Bull Chart Inst Ecol Environ Manag 100:29-34

Tryjanowski P, Kuźniak S, Sparks T (2002) Earlier arrival of some farmland migrants in western Poland. Ibis 144:62-68

Tyler SJ (1994) Turtle Doves feeding on corydalis seeds in southeast Wales. Br Birds 87:273

Urcun J-P, Gougeon ludovic, Lebost E, Le Bris Y (1995) Etude de la migration prénuptiale à la Pointe de Grave (Gironde): printemps 1994. Ligue pour la protection des oiseaux

Vreugdenhil-Rowlands J (2020) Turtle Doves in a Changing Landscape. Gaining Insight into the Daily Movements of Turtle Dovesin relation to the landscape. Mid-Project Report: Field Season 2019

Publisher's Note Springer Nature remains neutral with regard to jurisdictional claims in published maps and institutional affiliations. 